\title{
安全·安心な社会を支える薬学研究の新展開 〜若手の視点からの提言〜
}

山下浩平, ${ }^{*}, a$ 吉田 徳 幸, ${ }^{a}$ 木村恵理子 $b$

\section{New Developments of Pharmaceutical Research to Support Secure and Safe Society}

\author{
Kohei Yamashita, ${ }^{*, a}$ Tokuyuki Yoshida, ${ }^{a}$ and Eriko Kimura ${ }^{b}$ \\ ${ }^{a}$ Laboratory of Toxicology and Safety Science, Graduate School of Pharmaceutical Sciences, Osaka University; \\ 1-6 Yamadaoka, Suita, Osaka 565-0871, Japan: and ${ }^{b}$ Faculty of Pharmaceutical Sciences, \\ Josai University; 1-1 Keyakidai, Sakado, Saitama 350-0295, Japan.
}

近年，ナノテクノロジーやゲノム創薬・プロテ オーム創薬といった 21 世紀テクノロジーが劇的に 進歩している.これによって，抗体医薬等を始めと するバイオ医薬品や薬物送達担体としてのナノマテ リアルなど, 数多くの新規化学物質が続々と産み出 されている，新規化学物質は，従来までの素材と比 較して安定性・指向性・機能性・反応性の点で従来 素材とは異なる性質を示すため，利便性や有用性の 高い新規素材として，既に医療・香粧品・工学・食 品分野を始めとする様々な分野で使用され始めてい る. その一方で昨今, 食品中へのメラミンやメ夕ミ ドホスの混入事件や，原発問題など，安心・安全な 生活を脅かす問題が多発している。このような状況 も相俟って，われわれ消費者の薬・食・環境の安全 に対する懸念や健康への関心は年々高まり続けてい る.したがって，今後，新たに創製あるいは利用さ れる新規化学物質は, 有用性に加えて, ヒトの健康 や環境に対する安全性をも具備していることが強く 求められ，まさに社会現象となっている.

しかしながら，21 世紀テクノロジーにより創出 された新規化学物質の安全性評価は，世界的に見て も大きく立ち遅れている。例えば，バイオ医薬品や ナノマテリアル等は, 体内動態や生体影響の点で従 来素材とは全く異なる性質を示す可能性が考えられ るため, 従来手法に加えてより精度・感度の高い新

a大阪大学大学院薬学研究科毒性学分野 (T565-0871 大阪府吹田市山田丘 1-6), b城西大学大学院薬学研究 科薬粧品動態制御学講座（于350-0295 埼玉県坂戸市け やき台 1-1)

*e-mail: yamasita@phs.osaka-u.ac.jp

日本薬学会第 131 年会シンポジウム GS03 序文
たな安全性評価手法の開発が求められる。また，単 にハザードを明らかにするだけでは，新規化学物質 の毒性情報のみが独り歩きしてしまい, 結果として 有用な製品シーズを闇に葬ることになりかねない. 例えば，代表的な新規化学物質の 1 つであるカーボ ンナノチューブ (CNT) は，アスベストと同様に 中皮腫の発症を誘導することが報告されている。し かし，これら報告は，体内吸収性や体内動態といつ た曝露実態を全く加味していないうえ, CNT の物 性（長さや太さ等）と生体影響との関係が精査され ておらず，すべての CNT が安全でないと勘違いさ れかねない。すなわち，素材の曝露実態や物性を加 味することなくハザード情報のみが独り歩きするこ とによって，すべての素材が危険であるかのような 誤つた風評が広がってしまい, CNT の社会受容が 阻害される可能性がある。これでは，技術立国・知 財立国を目指すわが国の発展，そして何より，われ われが最先端技術の恩恵を享受し，豊かな生活を謳 歌する機会を奪いかねない。安全そして安心は第一 義的に重要であることは言うまでもないが，一方で こういつたハザード情報の独り歩きによる社会受容 の阻害は, 今後, 続々と開発されるである新規化学 物質についても同様に起こり得ることである，知財 立国・健康立国を目指すわが国において，今後は，

1）新規化学物質の使用量と環境中への放出量の調 査，2）ヒトに対する曝露経路・曝露量を始めとし た曝露実態と生体影響の関係性，3）生体内におけ る吸収・分布・代謝・排泄の評価，4）妊娠や加齢 といつた様々な健康状態における検討など，これら 新規化学物質に対する安全性評価に向けてあらゆる 
視点からの基礎情報の収集, 及び高確度かつ高精度 な新規安全性評価手法の確立が緊急課題とされてい る.

このような背景の下，今後の薬学領域には，新規 化学物質に対してその性能や安全性を客観的に評価 する方法論の開発に加え，これらを基盤とし，科学 的根拠に基づいたヒトの健康確保が強く求められて いる。 そこで本誌上シンポジウムは，上記課題に対 して取り組む若手研究者の研究を紹介した，昨年の 日本薬学会大学院生シンポジウムに基づいた企画で ある. 本誌では, 新規化学物質として微粒子素材, 及び環境中に流出した化学物質に焦点を当て，生体 に対する安全性評価を中心に，木村，吉田，山下， 戸次らの稿で紹介する，また，新規医薬品に対する 安全性評価手法の確立に向けた検討として，血中
microRNA，腸内細菌と薬物代謝酵素の関連につい て志津，石井らの稿で紹介する．これらの研究成果 が，新規化学物質の行政，専門家，企業，市民にお ける相互の意思疎通（リスクコミュニケーション） のきっかけとなり, 将来的に, 最先端技術の進展や 社会への浸透とともに，健康被害に対する予防・対 応策の確立や質の高い環境保全にも資することを期 待したい.

\section{謝辞本研究は, 大阪大学薬学研究科毒性学分} 野教授 堤 康央先生, 城西大学薬学研究科薬粧品 動態制御学講座教授 杉林堅次先生を始めとする多 くの先生方のご指導の下，遂行されたものであり， この場をお借りして御礼を申し上げます。 